\title{
PENERAPAN POLA PELAYANAN YESUS
}

\section{Ezra Tari}

\section{Program Studi Pendidikan Agama Kristen Ssekolah Tinggi Agama Kristen Negeri Kupang}

Email: tariezra@gmail.com

\begin{abstract}
ABSTRAK
Penerapan Pola Pelayanan Yesus.Tujuan penulisan adalah untuk memaparkan penerapan pola pelayanan Yesus. Gereja yang dimaksud adalah suatu realitas rohani di dalam dunia ini.Sebagai warga gereja yang dewasa terpanggil serta bertanggungjawab dalam memperkenalkanYesus Kristus.

Jenis penelitian yang digunakan yaitu berdasarkan metode kualitatif yakni data yang dikumpulkan dengan observasi dan wawancara. Penelitian ini menggunakan teknik deskriptif yaitu menguraikan, atau memaparkan dalam kalimat.Penelitian menggunakan metode penelitian kualitatif berdasarkan kepustakaan (library research). Penulis mengumpulkan data-data dari pustaka yang berbicara mengenai pola pelayanan Yesus, khususnya tugas Yesus yang diemban-Nya yakni mencari dan menyelamatkan yang berdosa. Pengumpulan data, juga diperoleh dari observasi atau pengamatan terhadap gejala yang terjadi dalam kehidupan orang percaya.

Penelitian ditemukan bahwa, pelayan membutuhkan pembinaan dan pendampingan dari majelis jemaat. Penerapan Pola pelayanan Yesus Keluarga menjadi dasar pembentukan sikap dan kepribadian pelayan untuk belajar mengenal kemudian melibatkan Allah dalam kehidupannya sejak dari kecil. Pelayanan yang berkarya setiap hari.
\end{abstract}

Jumlah kata : 150 kata

Kata Kunci : Pola Pelayanan, Yesus 
Gereja mendapatkan jati diri, hidup serta pengharapannya dalam dari Yesus Kristus.Gereja dipahami sebagai karya Kristus dalam suatu persekutuan dan mengutusnya sebagai pelayan dunia.Pelayanan gereja adalah tanggungjawab warga gereja sebagai persekutuan umatdalam Yesus Kristus.Seluruh umat Kristiani memiliki amanat Agung dalam mewartakan Injil Yesus Kristus karena persekutuan warga adalah menindaklanjuti pelayanan Yesus Kristus. Salah satu amanat Agung bagi gereja dalam persekutuan yang diutus sebagai suatu karya Kristus sebagai pelayan dengan memberikan perhatiandan pelayanan kepada anak-anak sebagai generasi penerus masa depan gereja. ${ }^{1}$ Masa anak-anak merupakan tahap penting dalam pembentukan dasar-dasar kepribadian di kemudian hari. Anak-anak sejak masa dini diajar kehidupan untuk mengenal dan melayani Tuhan, serta gereja-Nya. Dikemudian hari, anak-anak dapat dipastikan menjadi tulang punggung gereja.

Gereja mempunyai tugas panggilan bagi anak-anak, yang apabila dilaksanakan maka akan tumbuh dan berkembang. Gereja bisa tumbuh dan berkembang bersama tugas panggilannya yang dilakukan oleh orang-orang Kristen yang bertanggung jawab terhadap gereja. Dalam gereja orang percaya menjadi anggotanya, yakni warga gereja yang dewasa dan bertanggung jawab.

Orang harus mengerahkan sebagian besar dari pelayanannya kepada bidang-bidang khusus di mana ia merasa akan lebih efektif khususnya keluarga. ${ }^{2}$ Gereja yang dimaksud adalah suatu realitas rohani di dalam dunia ini. Warga gereja yang dewasa terpanggil serta bertanggungjawab dalam memperkenalkan anak kepada Yesus Kristus dan memberikan dukungan yang dibutuhkan dalam perkembangan iman Kristiani. Mereka mengambil bagian dalam kegiatan Sekolah Minggu. ${ }^{3}$ Gereja dalam dunia mengemban tugas untuk melakukan misi perdamaian Allah dengan

\footnotetext{
${ }^{1}$ George Eldon Ladd, Teologi Perjanjian Baru (Bandung: Kalam Hidup, 2002), 326.

${ }^{2}$ Ronald W. Leigh, Melayani dengan Efektif (Jakarta: BPK Gunung Mulia, 2007 ), 189.

${ }^{3}$ Ruth S. Kadarmanto, Tuntunlah ke Jalan Yang Benar (Jakarta: BPK Gunung.
} 
mewujudkan tanda-tanda Kerajaan Allah yakni syalom.Gereja tidak dapat mengingkari tugasnya yakni penggilan bersekutu, melayani dan bersaksi sebagai wujud nyata iman, pengharapan dalam pelayanan kepada sesama.Pelayanan gembala adalah model bagi pemimpin organisasi. Pemimpin dituntut untuk bertindak sebagai gembala sejati atas organisasi sebagai komunitas manusia. Loyalitas pengikut dan pengembangan organisasi dengan konsisten tergantung dari seorang pemimpin. Dengan mengikut Yesus berarti mewujudkan perintah-Nya yaitu; ajarlah mereka melakukan segala sesuatu yang kuperintahkan kepadamu (Mat 28:20). Perintah Yesus tidak hanya merupakan ajaran tentang iman. ${ }^{4}$

Dengan melihat situasi sekarang ini, harus diakui bahwa masih banyak jemaat yang belum cukup memberi perhatian memadai terhadap anak-anak.Pola pelayanan yang dikembangkan sering tidak memperhatikan kebutuhan anak-anak.Libatkan anak-anak dalam kelompok-kelompok gereja yang menekankan pelayanan.Memberi suatu teladan bagaimana suatu tanggung jawab memelihara iman anak-anak melalui kata dan perbuatan bagi mereka yang kurang beruntung. ${ }^{5}$

Alasan yang menguak cenderung bersifat paradigmatis: pandangan tentang anak, remaja dan pemuda. Implikasi dari kenyataan ini tidaklah mengherankan jika gereja kurang menempatkan pelayanan terhadap anak-anak maka akan melahirkan warganya yang tidak dapat menghadirkan kerajaan Allah dalam konteks dan realita kekinian.

Gereja sebagai persekutuan kudus yang lahir di dalam dunia melaksanakan amanat Yesus Kristus demi pertumbuhan dan perkembangan gereja itu sendiri. Seiring dengan perkembangan zaman, gereja dituntut untuk sanggup mengkaji dan merencanakan langkah-langkah yang perlu ditempuh untuk mencapai kondisi yang diharapkan dalam pelayanan terhadap umat-Nya.Untuk dapat melayani efektif maka seorang pelayan yang juga adalah seorang pemimpin perlu memiliki dan menyadari motivasi yang dimilikinya. Menurut Daniel Ronda, "Kunci utama dari pelayanan

\footnotetext{
${ }^{4}$ Andar Ismail (peny.), Ajarlah Mereka Melakukan (Jakarta: BPK Gunung Mulia, 2009), 22.

${ }^{5}$ Anne Neufeld Rupp, Tumbuh Kembang Bersama Anak (Jakarta: BPK Gunung Mulia, 2009), 228.
} 
yakni memeriksa motivasi dalam melaksanakan tugas dalam gereja". ${ }^{6}$ Pola kepemimpinan Yesus bukan untuk dilayani tetapi melayani dan berkorban untuk menebus banyak orang.Maka penting bagi umat Kristen sebagai para pengikut Yesus untuk mengikuti tujuan dan pola hidup Yesus dalam kehidupan setiap hari.Para murid perempuan muncul sebagai teladan kemuridan yang menderita dan kepemimpinan yang sejati. ${ }^{7}$

Dalam relasi itu, terdapat suatu dinamika yang merangkum banyak hal yang ikut berperan dalamnya relasi yakni: karya Allah dan usaha manusia, sarana komunikasi, sikap dan aktifitas secara sadar maupun tidak sadar.Keutamaan hidup yakni iman, pengharapan dan kasih dipahami sebagai komunikasi pribadi manusia dengan Tuhan.Dengan anugerah iman, manusia dimampukan untuk mengenal rencana Allah, percaya pada sabda Allah, dan menyerahkan hidupnya pada Allah sebagai andalan hidupnya. Dengan anugerah kasih, manusia menerima Allah sebagai kasih (1Yoh 4:8,16). Masalah sebenarnya berkaitan dengan sumberdaya manusia yaitu pelayan sekolah minggu. Sulit mencari pelayan sebab sebagaian pelayan sekolah minggu mengundurkan diri dari pelayanan setelah menikah, atau pindah kota setelah menyelesaikan kuliah.

\section{Pengertian Pola Pelayanan}

Pengertian pola menurut Kamus Besar Bahasa Indonesia adalah"gambar yang dipakai, model, sistem, cara kerja, bentuk atau struktur yang tetap. ${ }^{, 8}$ Pola pelayanan adalah gambaran atau cara kerja pelayanan yang dilakukan. Istilah pelayanan yang sering terdengar adalah service. Pelayanan ini dibidang bisnis dan jasa umum atau transportasi yang melayani bukan tanpa pamrih. ${ }^{9}$ Kamus Besar Bahasa Indonesia, dari kata layan menjadi melayani artinya orang yang

${ }^{6}$ Daniel Ronda, Leadership Wisdom (Bandung: Kalam Hidup, 2011), 73.

${ }^{7}$ Roy Eckardt, Menggali Ulang Yesus Sejarah (Jakarta: BPK Gunung Mulia, 2006), 187.

${ }^{8}$ Kamus Besar Bahasa Indonesia, s.v, "Pola"

${ }^{9}$ Emanuel Gerrit Singgih, Reformasi dan Transformasi Pelayanan Gereja Menyongsong Abad 21 (Yogyakarta: Kanisius, 1997), 15. 
pekerjaannya melayani, pembantu, jadi pelayanan berarti berusaha melayani kebutuhan orang lain dengan memperoleh imbalan. ${ }^{10}$

Secara etimologi, kata "pelayanan" memiliki makna yang amat kompleks. Dalam bahasa

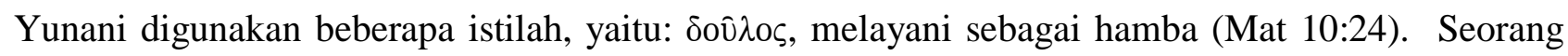
budak adalah seorang yang sama sekali tidak memiliki kepentingan diri sendiri. Dalam ketaatan penuh kerendahan hati ia hanya bisa berkata dan bertindak atas nama tuannya. Dalam hal ini tuannya berbicara dan bertindak melalui dia. Hamba tidak pernah mendapat pujian apalagi imbalan yang pantas. $\delta\llcorner\eta \kappa o ́ v \in \iota$, melayani sebagai pelayan dapur, yang menantikan perintah di sekitar meja makan (Mat. 8:15). Ini bukan pekerjaan yang menyenangkan, karena seringkali ia akan menerima kata yang kasar dari orang yang merasa kurang puas dilayani. Dalam arti luas kata ini menyatakan seseorang yang memperhatikan kebutuhan orang lain, kemudian berupaya untuk dapat menolong memenuhi kebutuhan itu. Orang bisa saja bekerja sebagai budak (doulos) dan tidak menolong

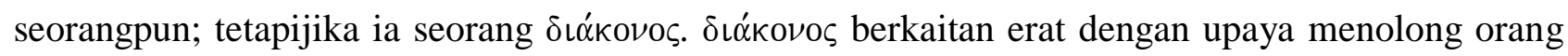
lain (Yoh. 12:26; Tim. 3:13). ${ }^{11}$ Kata pelayanan dalam kehidupan Kristen berarti pelayanan kepada Tuhan. Pelayanan bersifat rohani sepert 9 , kebaktian dan doa. Pelayanan sebatas ritual atau rohani. Melayani menyangkut persoalan konkret di bidang etik. ${ }^{12}$ Melayani orang lain merupakan tugas pelayan, “... layanilah seorang akan yang lain oleh kasih” (Gal 5:13). Siapa yang mengasihi lebih, bertindak lebih.

8

Pola perspektif segala sesuatu harus berdasarkan kehendak Allah yang bertujuan membawa kemuliaan bagi nama-Nya. Kriteria dasar pola pelayan inkarnasi terlihat beberapa tekanan yang harus merupakan sikap seorang individu. Model mengembangkan diri memberikan prinsip yaitu

\footnotetext{
${ }^{10}$ Kamus Besar bahasa Indonesia, s.v. "Layan"

${ }^{11}$ Petrus F. Setiadarma, "Motivasi Pelayanan", diakses tanggal 16 Oktober 2012, tersedia di http://motivasi-pelayanan.html,

${ }^{12}$ Emanuel Gerrit Singgih, Reformasi dan Transformasi Pelayanan Gereja Menyongsong Abad 21 (Yogyakarta: Kanisius, 1997), 16.
} 
memberi dan menerima (Kis 20:35). ${ }^{13}$ Intinya pelayanan dapat dikatakan sebagai suatu upaya membantu orang lain untuk memenuhi kebutuhan hidupnya.

Apabila dikaitkan dengan tingkatan kebutuhan yang bersifat hierarkis, maka pelayanan dan kebutuhan akan terkait satu sama lain. Pelayanan timbul karena adanya kebutuhan yang berkembang, begitu pun kebutuhan akan terus berkembang seiring dengan proses pelayanan yang berjalan, dalam arti setelah pelayanan yang diselenggarakan terhadap satu jenis kebutuhan maka akan memunculkan kebutuhan yang baru lagi. Sehingga dalam penyelenggaraan pelayanan(kegiatan sosial) pada umumnya terkait pada 2 orientasi, antara lain :

Pertama, Value-Rationality, artinya kegiatan ini secara sadar ditentukan melaluinilai-nilai individu demi kepentingan masyarakat. Formulasi nilaiutama sangat mendukung terhadap dilakukannya suatu kegiatan, tanpamemperhatikan konsekuensinya.

Kedua, Instrumental-Rationality, artinya bahwa kegiatan yang dilakukan telahmemperhatikan, memperhitungkan dan mempertimbangkan maksud,tujuan dan konsekuensinya.Kedua konsep tersebut sangat berpengaruh terhadap birokrasi yangmenjalankan tugas memberikan pelayanan kepada masyarakatnya. Namuntindakan mereka tidak selalu efektif dan juga tidak tradisional.

Yesus menerapkan cara hidup dan pelayanan dengan menyuarakan kebenaran. KedekatanYesus denganBapa-Nya melahirkan kepedulian dan kritis terhadap kehidupan manusia dan ciptaan lainnya.Gereja dalam kehidupan pelayanan dapat mengambil pola Yesus yang membasuh kaki. ${ }^{14}$ Kedekatan dengan Tuhan membuat pelayan berani untuk pergi menjadi saksisaksi yang hidup, baik di dalam persekutuan maupun dunia pada umumnya. Penyerahan diri total kepada Yesus menjadi syarat untuk mengikuti kehendak Allah, sehingga pelayan mampu melayani tanpa pamrih (Mrk. 10:45). ${ }^{15}$

\footnotetext{
${ }^{13}$ Yakob Tomatala, Pemimpin Yang Handal (Jakarta: YT Leadership, 2003), 12.

${ }^{14}$ Paulinus Yan Olla, Dipanggil Menjadi Saksi Kasih (Yogyakarta: Kanisius, 2011), 218.

${ }^{15}$ E.B. Subakti, Benarkah Injil Kabar Baik (Jakarta: BPK Gunung Mulia, 2008), 113.
} 
Dalam pelayanan-Nya, Yesus mengajar dan menyembuhkan dari kota ke kota. Tuhan Yesus mengetahui cara menghadapi setiap orang dengan metode yang berbeda. Pelayanan Yesus menerapkan metode sesuai dengan keadaan yang dihadapi orang misalnya perempuan yang kedapatan berzinah, Yesus memberi pengampunan (Mat 19:13-15). ${ }^{16}$ Ketaatan Yesus yang total kepada Allah yang membuat-Nya secara eksistensial dan total pula menaruh kepedulian kepada umat manusia dan seluruh ciptaan. Yesus mengungkapkan secara implisit bahwa, jalan menuju kebenaran adalah jalan pelayanan. Jalan menuju yang Dia sendirilah pola dan gambar yang dasariah dari pelayanan. (bnd. Luk 4:17-20). Allah mengurapi Yesus sebagai bagian dari kesaksian akan janji, di mana Yesus datang membawa perubahan. ${ }^{17}$

Yesus sangat mementingkan hubungan intim dengan Allah Bapa. Ia memahami persis pikiran, perasaan dan kehendak Bapa-Nya. Dalam segala waktu dan tempat Ia berkomunikasi dengan Allah Bapa. Ia mendahulukan kepentingan Allah melebihi segala-galanya. Yesus melihat manusia sebagai citra Allah pula. Ia sangat menghargai dan mencintai sesama manusia. Pengenalan akan diri bagi pelayan harus menyadari bahwa ia mudah marah atau tiba-tiba merasa takut. ${ }^{18}$ Orang percaya hendaknya meneladani Yesus dalam aspek horisontalnya. Dalam lingkungan kehidupan Kristen, pelayanan paling banyak dipakai sehubungan tugas di dalam gereja disamping kata mengasihi atau kasih yang menjadi penekanan ajaran. Pada umunya pelayanan diartikan sebagai ibadah, kegiatan spiritual, dan kegiatan ritual keagamaan. Pelayanan yang sebenarnya dapat dilihat dalam pola pelayanan-Nya yang holistik.

\section{Pola Pelayanan Yesus}

Kehadiran Yesus di dunia di kenal dengan inkarnasi yang berarti Allah mengambil rupa manusia secara utuh sama dengan manusia, bahkan mengambil rupa seorang hamba (Flp. 2:5-8). Dengan keberadaan sebagai manusia sederhana, Ia turut merasakan keberadaan manusia yang

\footnotetext{
${ }^{16}$ E. P. Gintings, Konseling Pastoral, (Jakarta: Jurnal Info Media, 2009), 34.

${ }^{17}$ Sostenis Nggebu, Napak Tilas Jejak-Jejak Yesus, (Bandung: Yayasan Kalam Hidup, 2004), 238.

${ }^{18}$ Robby I Chandra, Pendidikan Manusia Mandiri (Bandung: Generasi Indonesia, 2006), 107.
} 
sesungguhnya. Yesus menjadi Juruselamat yang utuh secara rohani dan jasmani.Yesus berkeliling kesemua kota dan desa; Ia mengajar dalam rumah-rumah ibadatdan memberitakan Injil Kerajaan Sorga serta melenyapkan

segala penyakit dan kelemahan(Mat 9:35).

\section{Gembala}

Shepherd dalam bahasa Inggris berarti domba sedangkan Ibrani kuno ra'ah artinya memberi makan sehingga gembala dikenal sebagai orang yang memberi makan dan dapat ditujukan kepada individu yang membantu atau memelihara orang lain.Dimana seseorang yang memperlihatkan kepedulian yang penuh kasih sayang. Deskripsi tugas dari kepemimpinan pastoral ada dalam 1 Petrus 5:1-8 yaitu memelihara dan mengawasi. Kata memelihara menunjukkan fungsi seorang gembala yaitu menyediakan makanan bagi domba-dombanya.

Implikasi pelayan gembala ialah seluruh gerak langkah dan pola pelayanan pemimpin Kristen mengikuti model kepemimpinan yang telah dilakoni oleh Yesus selama dia hidup di dunia ini.Kepemimpinan-Nya telah diabadikan oleh para murid-Nya dalam setiap Injil yang telah dicatat secara lengkap.Melayani merupakan prinsip dasar kepemimpinan Yesus dan dengan menjadi prinsip yang esensial dalam kepemimpinan Kristen.Berkorban dalam konteks melayani, Yesus membuktikan diri sebagai pemimpin yang berkorban.Jalannya pelayanan Yesus, kalau kita tinjau masa tiga tahun Yesus melayani nyata kepada kita bahwa ada suatu rencana yang diturutiNya.Bagian pertama dari pelayanan-Nya dipergunakan Yesus untuk memberitakan Kerajaan Sorga. ${ }^{19}$

Pengorbanan kepemimpinan Yesus sangat tinggi harganya, yaitu nyawa-Nya sendiri. NyawaNya dipertaruhkan demi kepentingan manusia. Yesus satu-satunya pemimpin sempurna yang

\footnotetext{
${ }^{19}$ J.H. Bavinck, Sejarah Kerajaan Allah 2 Perjanjian Baru( Jakarta: BPK Gunung Mulia, 2007) 125.
} 
melayani dengan sempurna. Itu sebabnya, Yesus sangat layak, sangat pantas sebagai pemimpin ideal dan pemimpin unggul yang patut diikuti.Dia memimpin sebagai hamba bagi Bapa-Nya di surga, yang menetapkan misi-Nya. Dalam pelayanan Yesus sebagai gembala, ialah bahwa Ia secara pribadi bergaul dengan orang-orang yang ditemui. Baginya tiap-tiap orang adalah lain, tiap-tiap orang mempunyai hidupnya sendiri. ${ }^{20}$

Gembala tidaklah sekadar mengetahui atau memahami keberadaan fisik secara visual semata, namun aspek yang lebih penting justru unsur lain yang tersembunyi di balik fisik tersebut, seperti naluri, karakter, atau tabiat. Mengenal secara fisik barulah sebagian dari eksistensi ternak secara utuh. Gembala yang baik adalah gembala yang mengenal ternak yang digembalakannya secara utuh. Namun, agar seorang gembala mampu mengenal ternaknya secara utuh, maka mau tidak mau, ia harus memiliki hubungan emosional yang intim dengan ternak gembalaannya.

Jika memandang secara cermat kehidupan Yesus, makadilihat bahwa apa pun yang dilakukanNya adalah dalam rangka pelayanan-Nya terhadap misi ini. Misi pribadi-Nya bukanlah untuk melayani keinginan-Nya sendiri, melainkan untuk memenuhi kehendak Bapa-Nya.Dia mengatakan, "Sebab Aku telah turun dari sorga bukan untuk melakukan kehendak-Ku, tetapi untuk melakukan kehendak Dia yang telah mengutus Aku" (Yoh. 6:38). ${ }^{21}$ Penyembuhan-penyembuhan-Nya adalah atas rakyat kecil yang sakit seperti orang buta dan orang timpang.Ia memberi makan kepada orang banyak, yaitu rakyat yang datang berkumpul mendengar pengajarannya tanpa bekal yang cukup. Pengajaran Yesus Kristus sendiri memihak kaum jelata. ${ }^{22}$

Syarat terpenting untuk menjadi seorang gembala yang berhasil ialah sifat yang tak tercela. Sifat itu memancar keluar seperti hal radiator yang panas. Seeorang dapat memberitakan injil melalui kehidupannya. Sifat seseorang bisa mempengaruhi orang-orang di sekitarnya dan dengan cara ini juga dapat mempengaruhi perubahan yang nyata dan hidup. Seorang gembala sidang selalu

\footnotetext{
${ }^{20}$ J.L Ch. Abineno, Pedoman Praktis Untuk Pelayanan Pastoral (Jakarta: BPK Gunung Mulia, 2006 ), 12 .

${ }^{21}$ G. Gene Wilkes,Jesus on Leadership: Temukan Rahasia Pelayanan dari Kehidupan Kristus(Jakarta: Bhuana Ilmu Populer, 2005), 11-14.

${ }^{22}$ Zakaria J. Ngelow, Gereja dan Masyarakat Madani di Indonesia (Jurnal Teologi Persetia, 1999),
} 
meninggalkan bekas kerohaniannya yang memiliki ciri khas tersendiri kepada jemaatnya, khususnya pada orang-orang yang bertobat di bawah pelayanannya. Oleh sebab itu sangatlah penting Roh Kristus yang menjadi nyata dalam kehidupan seorang gembala.

Roh Kristus harus menembus setiap segi dan tingkat kehidupan orang Kristen terutama kehidupan seorang gembala sidang. Demikian juga kontak dan hubungan dalam kehidupan gembala harus tak tercela. Sifat-sifat tertentu yang di sucikan oleh Roh Allah akan menguatkan benteng dan menarapribadi mengeluarkan kuasa yang sebenarnya dari pekerja itu.

\section{Pengajar/Guru}

Wewenang yang menyangkut hidup dan pekerjaan Yesus sebagai pengajar adalah Wewenang Yesus sebagai pengajar. Wewenang Yesus sebagai pengajar nyata dari pernyataan-Nya. Pernyataan murid-murid dan pengakuan orang lain, seperti Nikodemus seorang tokoh Farisi (Yoh 3:1-2). Wewenang itu nyata pula dalam perbuatan kasih-Nya bagi banyak orang.Dia mengajar atas dasar Firman Allah serta secara cakap membaca hati orang-orang yang dihadapi-Nya.

Yesus dalam menghadapi murid-murid-Nya dengan latar belakang yang berbeda.Yesus sebagai pribadi yang mengajar secara terus terang dengan tujuan yang jelas pula.Tujuan Yesus dalam mengajar ialah membentuk cita-cita luhur dalam diri para murid-Nya, membentuk keyakinan yang teguh, memiliki hubungan dengan Allah dan sesamanya.Para murid didorong-Nya agar kreatif menghadapi masalah hidup sehari-hari dan memiliki watak yang bagus dalam menjalankan tugas pelayanan.Pengajaran Yesus berhasil dalam rangka mengangkat derajat para murid, mengubah kehidupan mereka agar percaya kepada-Nya.

Yesus senantiasa menyesuaikan pengajaran-Nya.Dia menyentuh suara hati mereka serta merangsang mereka untuk aktif berbuat. Bahan pengajaran Yesus diambil dari Perjanjian Lama diintegrasikan dengan peristiwa alam dan peristiwa yang hangat yang sedang terjadi. Dia menggunakan pepatah, ilustrasi, perumpamaan dalam memulai atau dalam menjalankan pengajaran.Pengajaran Yesus amat menarik, diawali pendahuluan, isi dan kesimpulan. 
Kebergantungan Yesus yang amat sempurna kepada Allah Bapa itu mewarnai pola pikir dan sikap kita jika ingin berhasil dalam tugas mengajar atau mendidik. Selain itu, teladan Yesus sebagai manusia sejati yang rela belajar, harus mendorong orang percaya untuk rela berlatih, belajar mengembangkan diri dalam karunia yang Allah berikan guna mengajar orang lain. Yesus berkarya atas dasar tujuan yang jelas, yakni membina murid agar mengerti serta mengalami kekudusan Allah.Murid diajar-Nya agar menyadari diri sebagai hamba.Murid pun diajar agar hidup dalam relasi kasih dengan sesamanya.Sebagai hamba yang melayani sesama, serta mengarahkan mereka berdamai dengan Allah.

Cara Yesus melaksanakan tugas-Nya sebagai guru amat mengagumkan. Yesus memang unik namun Dia menjadi sama dengan murid-murid-Nya dan dengan orang-orang lain yang dilayani-Nya. Dia membaca apa kebutuhan mereka, pergumulan serta tingkat pengertian mereka. Dia "menjadi satu" dengan berita yang disampaikan.Tidak heran mengapa Yesus begitu berotoritas. Hal itu tampak dalam pernyataan-Nya: "Aku berkata kepadamu..." atau "Aku adalah..." teladan Yesus dalam kerelaan menjadi sama dengan orang yang dilayani dan perkara yang berkembang dalam hati seorang guru jika ia hendak membawa pembaruan.

Yesus mengarahkan murid mencapai target dalam hal apa yang diperbuat mereka. Artinya, relasi tidak hanya sebatas kata, ucapan dan peristiwa sewaktu-waktu.Dalam mengajar, Yesus membuat murid-murid aktif dan senantiasa di dalam keaktifan, apakah berpikir, merasa dan memberi respons serta berbuat. Dia pun mengajar melalui perbuatan nyata seperti mujizat, diskusi dan tanya jawab. Dia senantiasa memberi dorongan untuk bertindak.Teladan Yesus mendasari nilai hidup dan pemikiran pelayan.Perbuatan mendidik maupun mengajar, pelayan menekankan kebersamaan, keaktifan dengan tujuan jelas.Peringatan terhadap gereja disampaikan oleh Donald McGavran yang mengatakan "Tuhan menghendaki agar domba-domba-Nya yang hilang ditemukan dan dibawa kembali ke kandangnya.",23

\footnotetext{
${ }^{23}$ C. Peter Wagner, Strategi Perkembangan Gereja ( USA: Gospel Literature International, 1998),
} 
Ketujuh,Yesus tidak saja mendekati dan melayani orang banyak (massa). Dalam mencapai dunia dengan Injildi kalangan umat Yahudi. Setiap kesempatan berinteraksi dengan manusia apakah pribadi atau kelompok bahkan dengan massa, mesti diupayakan dengan baik dan tepat. Dia harus menyadari potensi yang ada dalam sekolah minggu.Keberhasilan seorang gembala sering kali diukur dari seberapa besar sekolah minggunya. Gembala yang bijaksana tentunya akan mengerti bahwa lebih banyak orang yang datang ke sekolah minggu, berarti lebih banyak yang terjangkau bagi Tuhan. Sekolah minggu yang terorganisasi dengan baik, yang hidup, dan berkembang menunjukkan sebuah gereja yang hidup dan bertumbuh.Menurut Gunche Lugo, Yesus tidak beorientasi merebut kekuasaan atau pemerintahan, tetapi moral (etik). Pola Yesus adalah politik memperjuangkan tegaknya nilai-nilai keadilan, kebenaran, kesejahteraan, dan kemajuan peradaban dalam masyarakat. ${ }^{24}$

\section{Hamba}

Yesus Kristus meninggalkan teladan bagi pelayan atau Hamba Tuhan untuk diteladani.Dalam pelayanan orang percaya diharapkan menyerupai Kristus kepala dan gembala.Orang percaya patut mengupayakan keserupaan dengan Kristus sebagai kepala yang menghamba dan sebagai gembala baik. Kristus sebagai Kepala gereja dimengerti dalam arti hamba, sesuai dengan apa yang dikatakan-Nya tentang diri-Nya sendiri: “Anak Manusia datang bukan untuk dilayani, melainkan untuk melayani dan untuk memberikan nyawa-Nya menjadi tebusan bagi banyak orang." (Mat 20:28).

Pelayanan-Nya sebagai hamba nyata dalam pengabdian dengan memberikan diri-Nya bahkan menyerahkan hidup-Nya di kayu salib.Hamba dalam arti berserah diri sepenuhnya dalam cinta kasih dan kerendahan hati. Ia merendahkan diri sebagai seorang Hamba dan taat sampai mati di salib: "Hendaklah kamu dalam hidupmu bersama, menaruh pikiran dan perasaan yang terdapat juga dalam Kristus Yesus, yang walaupun dalam rupa Allah, tidak menganggap kesetaraan dengan Allah itu sebagai milik yang harus dipertahankan, melainkan telah mengosongkan diri-Nya sendiri,

\footnotetext{
${ }^{24}$ Gunche Lugo, Manifesto Politik Yesus(Yogyakarta: Penerbit ANDI, 2009), 42.
} 
dan mengambil rupa seorang hamba, dan menjadi sama dengan manusia. Dan dalam keadaan sebagai manusia, Ia telah merendahkan diri-Nya dan taat sampai mati, bahkan sampai mati di kayu salib" (Flp 2:5-8).

Menurut Stefan Leks kata hamba, dalam Injil Markus, mengacu kepada fungsi seorang bawahan (Mrk 12:2,4; 13:34;14:7). Seorang hamba tergantung secara hampir menyeluruh dari majikan yang dilayaninya. Namun, dalam teks ini, majikan itu bukan seorang individu melainkan seluruh komunitas Kristen. ${ }^{25}$ Komunitas Kristen justru dikenal bukan pada syarat untuk melayani melainkan memberi diri seperti seorang hamba. Pemahaman banyak orang tentang melayani Tuhan adalah aktif dalam kegiatan rohani di lingkungan gereja, yaitu dengan mengambil bagian dalam tugas tertentu. Sesungguhnya anggapan seperti ini justru membuat mereka tidak pernah melayani Tuhan dengan benar, sebab yang terbangun adalah anggapan bahwa segala kegiatan di luar lingkungan gereja bukanlah pelayanan bagi Tuhan. Sebenarnya yang dimaksud dengan melayani Tuhan adalah melakukan apa saja yang dikehendaki-Nya. Tentu ini bukan hanya dalam melakukan kegiatan gereja, tetapi dalam kehidupan kita sehari-hari. Jangan sampai di gereja kita menjadi pelayan Tuhan, di luar gereja menjadi pelayan setan. Menghambakan diri berarti memberi diri untuk melakukan apa saja yang dikehendaki-Nya. Sikap seorang hamba digambarkan sebagai sikap yang ditunjukkan dalam pelayanan.

Pelayanan gembala memiliki karakteristik mendengarkan, empati, menyembuhkan, kesadaran, daya persuasi, konseptualisasi, menatap masa depan penatalayanan, komitmen pada pertumbuhan orang, dan membangun komunitas. Yesus pun membekali mereka dengan otoritas untuk mengusir setan dan melenyapkan segala penyakit. Ia menentukan cara pelayanan mereka, yaitu pelayanan bersama dengan orang lain, bekerja bersama-sama, dan bersama-sama bekerja. Sasaran yang dituju sudah ditentukan oleh Sang Pengutus.Perintah kerja juga dirincikan detail yaitu menyatakan kuasa kerajaan surga secara nyata. Duta melakukan pekerjaan ke segala tempat bukan dalam rangka wisata, tetapi menggenapi tuntutan tugas mulia dari Yesus yaitu

\footnotetext{
${ }^{25}$ Stefan Leks, Tafsir injil Markus (Yogyakarta: Kanisisus, 2007 ), 362.
} 
menyampaikan Injil Kerajaan Sorga.

\section{Pelayan dan Pembimbing}

Misi Yesus sendiri dicirikan oleh perkataan (pemberitaan) dan sekaligus perbuatan (kesaksian), dan yang satu menjelaskan yang lain. Untuk hal itu, Yesus kemudian mengatakan "Kamu adalah saksi dari semuanya ini” (Luk 24:47-48), dan "kamu akan menjadi saksi-Ku di Yerusalem dan di seluruh Yudea dan Samaria dan sampai ke ujung bumi” (Kis 1:8).Murid-murid diutus untuk menjadikan semua bangsa murid-Nya dan mengajarkan kepada mereka segala sesuatu yang telah diperintahkan Yesus (Mat 29:19-20).

Seorang gembala yang baik harus mempunyai hati yang rela berkorban, meskipun menghadapi kesulitan juga tidak akan meninggalkan dan membiarkan domba-dombanya.Ia mengenal setiap dombanya, juga bersedia membawa domba yang berada di luar menyediakan dan mencukupi segala kebutuhan dombanya, termasuk kebutuhan intelektual, emosi, mental, dan rohani.Sebagai hamba Tuhan, setiap pelayan sudah selayaknya memikirkan pelayanan secara utuh, sebab pemikiran, saran, dan ide-idenya sangat dibutuhkan dalam setiap bidang pelayanan, termasuk anak-anak.Peranan hamba Tuhan dalampelayanan dan penggembalaan sangat diharapkan. Pelayanan terhadap manusia sesuai dengan konteks keberadaan orang yang dilayani. Kerendahan hati adalah guru yang hebat jika dikembangkan dengan maksimal. Pekerjaan Yesus yang paling banyak adalah menyembuhkan dan kehadiran-Nya bagi orang banyak. Menurut Herlianto: "Pelayanan seutuhnya adalah mencakup pemberitaaan injil baik secara verbal yang menjangkau manusia seutuhnya yakni, kebutuhan manusia baik roh maupun sosial budaya.,"26

Visi Yesus jelas yaitumembawa kebaikan dan sukacitabagi manusia bukan sebaliknyamengorbankan orang banyak untukkepentingan pribadi. Orientasikepemimpinan-Nya bukan padakedudukan tetapi lebih padapelayanan yang membawakebaikan bersama. Untuk itu Diatidak mulai dengan tuntutan tetapi memberikan teladan yang mendorong orang melakukan hal yangsama yaitu saling melayani.

\footnotetext{
${ }^{26}$ Herlianto, Pelayanan Perkotaan (Bandung: Yabina, 1998), 132.
} 
Yesus tidak pernah melayani diri-Nya sendiri. Dia memimpin sebagai hamba bagi Bapa-Nya di surga, yang menetapkan misi-Nya. Jika memandang secara cermat kehidupan Yesus, melihat bahwa apa pun yang dilakukan-Nya adalah dalam rangka pelayanan-Nya terhadap misi ini. Misi pribadi-Nya bukanlah untuk melayani keinginan-Nya sendiri, melainkan untuk memenuhi kehendak Bapa-Nya. Dia mengatakan, "Sebab Aku telah turun dari sorga bukan untuk melakukan kehendak$\mathrm{Ku}$, tetapi untuk melakukan kehendak Dia yang telah mengutus Aku" (Yoh. 6:38).

Setiap orang yang dipanggil-Nya untuk menjadi guru sekolah minggu pasti akan dipanggilNya secara khusus. Setiap pelayan dipanggil pada misi penyelamatan anak. Dengan meyakini panggilan ini, pelayan akan semakin bertambah semangat untuk melayani. Panggilan adalah karunia dan kepercayaan dari Tuhan. Perhatikan: "... karena Allahlah yang mengerjakan di dalam kamu baik kemauan maupun pekerjaan menurut kerelaan-Nya" (Filipi 2:13). Allah rela memercayakan sebuah pelayanan kepada umat-Nya. Jika menjadi pelayan sekolah minggu, karena umat diutus Tuhan. Bukan karena kehendak siapa-siapa, melainkan karena diutus-Nya. Panggilan pelayanan bersikap seperti anak kecil, menunjukkan bahwa sikap demikian dibutuhkan supaya dapat masuk dalam kerajaan Allah. $^{27}$

Kristus sebagai dasar penggembalaan Perjanjian Baru, prinsip-prinsip penggembalaan sebagaimana terdapat dalam Yohanes 10:1-29 yakni, Yesus menekankan perihal gembala yang sejati sebagai lawan gembala yang mempunyai motif yang egois dan tersembunyi.Karakter gembala sejati menjadikannya seorang gembala penjaga.Gembala sejati mempunyai komitmen untuk memberikan nyawanya bagi domba-dombanya.Tujuan gembala yang baik ialah untuk memberi hidup yang berkelimpahan kepada kawanan domba itu.Kehidupan-Nya mencerminkan pikiran-Nya dan menambahkan kebenaran dalam pengajaran-Nya. ${ }^{28}$

Gembala yang penuh kasih berusaha untuk memberi keamanan kepada dombanya dan berusaha memenuhi kebutuhan-kebutuhannya.Gembala yang menelantarkan dombanya secara

\footnotetext{
${ }^{27}$ Henk Ten Napel, Jalan Yang Lebih Utama Lagi (Jakarta: BPK Gunung Mulia, 1990), 79.

${ }^{28}$ Jody Capehart, Becoming a Treasured Teacher: Practical Strategies for Making a Lasting Difference in Young Lives (Victor Books, 1992), 11-12.
} 
langsung dan tak langsung telah menempatkan kawanan dombanya dalam ancaman bahaya.Gembala jemaat tidak boleh kehilangan cinta kasihnya kepada orang-orang yang ada di luar jemaat.Mengenali kehadiran Allah yang aktif ditengah-tengah jemaat adalah tujuan utama dari tindakan penggembalaan.

Panggilan seorang gembala jemaat berakar di dalam wewenang Allah. Dasar panggilan Yesaya ialah suara Allah (Yes. 6:1-4); pelayanan Amos juga diawali dengan penugasan dari Allah (Am 7:14-16). Allah menugaskan Yehezkiel untuk berkhotbah sekalipun umat-Nya tidak mau mendengarkan (Yeh. 2:2-3). Perjanjian Baru mengungkapkan panggilan untuk pelayanan pemberitaan Firman berakar di dalam penugasan Allah langsung (Rm 10:14).

\section{Panggilan Pelayanan}

Yesus dengan setia memenuhi panggilan Bapa-Nya, meskipun panggilan tersebut berakhir pada siksaan dan kematian.Meskipun Tuhan Yesus memahami bahwa kematian-Nya sudah dekat, namun Ia tetap giat di dalam pelayanan-Nya. Ia berkeliling kota dan desa untuk mengajarkan Injil Kerajaan Allah. Panggilan pelayanan bukanlah pengalaman sekali seumur hidup melainkan merupakan tanggapan murid yang berkelanjutan. ${ }^{29}$

Yesus juga menunjukkan betapa Ia tidak membeda-bedakan pelayanan. Ia pergi ke kotakota, dan cacat, dan yang lemah. Teladan Yesus yang diambil dari Markus 10:13-16, dikenal sebagai orang yang ramah dan terbuka untuk anak-anak (ay. 13). Lalu orang membawa anak-anak kecil kepada Yesus, supaya Iamenjamah mereka; akan tetapi murid-murid-Nya memarahi orangorang itu. Seorang pelayan anak perlu memiliki sikap seperti seorang pelayan anak dekat dekat dengan anak-anak, selalu membuka tangan untuk mereka, dan mau direpotkan oleh segala tingkah laku anak-anak. Orang tua pun akan merasa aman memercayakan anak-anaknya.

Seorang pelayan anak yang pasti akan menyambut anak mereka dengan sukacita. Tidak menghalang-halangi anak datang kepada Allah (ay. 14). "Ketika Yesus melihat hal itu, Ia marah dan berkata kepada mereka, "Biarkan anak-anak itu datang kepada-Ku, jangan menghalang-

\footnotetext{
${ }^{29}$ Eddy Gibbs, Kepemimpinan Gereja Masa Mendatang ( Jakarta: BPK Gunung Mulia, 2010 ), 144.
} 
halangimereka, sebab orang-orang yang seperti itulah yang empunya KerajaanAllah.” Panggilan sama artinya dengan membuka jalan bagi semua bagi pemaafan diri atas performa yang tidak baik. Panggilan pelayanan merupakan tanggapan bebas terhadap panggilan tugas dengan cinta demi pelayanan kepada semua. ${ }^{30}$

Yesus memarahi para murid-Nya yang telah menghalangi anak-anak itu datang kepada-Nya. Walaupun anak-anak masih kecil dan mungkin belum menyadari maksud orang tua mereka membawa mereka kepada Yesus. Yesus tetap menghargai jiwa setiap anak-anak itu.Sama seperti orang dewasa yang saat itu mengelilinginya, anak-anak juga mendapat kesempatan yang sama untuk datang kepada-Nya. Bahkan Dia menyiratkan, hanya dengan menjadi seperti anak kecil itulah seseorang dapat masuk Kerajaan Allah.

Oleh kedaulatan-Nya, Allah menetapkan dan memanggil setiap pemimpin kepada tugas dan tanggung jawab kepemimpinan (Mat 20:23b, Mrk 10:40; band. Rm 12:6-8; 8:29-30). Kepemimpinan Kristen dibangun di atas hubungan-hubungan sebagai landasan kerja dan keberhasilan kepemimpinan. Yesus membangun kepemimpinan-Nya di atas hubungan-hubungan dengan terencana. Ia memanggil para murid-Nya dan melibatkan mereka ke dalam "kehidupan kelompok". Sehingga melalui wahana kelompok kecil tersebut mereka diajar, dan dilengkapi untuk menjadi pemimpin (Mat 20:20-23; Mrk 10:35-40; bnd. Mat 10: 1-15; Mrk 3:13-19; Luk 6:1216).Pelayanan Yesus secara langsung kepada suatu dunia yang secara hakiki berbedaprinsip-prinsip dari pelayanan-Nya. ${ }^{31}$

\section{Kewajiban Pelayanan}

Kepemimpinan Kristen diteguhkan di atas model kepemimpinan "pelayan hamba" yang merupakan landasan etika-moral bagi kepemimpinan, serta pola dasar manajemen dalam kepemimpinan. Sebagai model dasar kepemimpinan, para pemimpin Kristen perlu membangun sikap etis-moral sebagai "pelayan yang melayani" dan "hamba yang mengabdi" yang merupakan

\footnotetext{
${ }^{30}$ Richard M Gula, Etika Pastoral Dilengkapi dengan Kode Etik (Yogyakarta: Kanisius, 2009), 27.

${ }^{31}$ David J. Bosch, Transformasi Misi Kristen( Jakarta: BPK Gunung Mulia, 2006), 53.
} 
landasan bagi etos kerja. Sebagai pola dasar manajemen, model kepemimpinan pelayan-hamba ini memberikan tekanan kepada kerja yang berorientasi kepada keberhasilan (Mat 20:24-28; Mrk 10:42-45; band. Ibr 13:7,17; Kol 3:23; 1Ptr 2:18-25; Luk 17:10). ${ }^{32}$ Kepemimpinan Kristen berfokus kepada "melayani" (service) dengan memberikan yang terbaik.

Fokus melayani ini menegaskan perlunya komitmen dan tindakan untuk mewujudkan yang terbaik dengan membayar harga, serta konsekuensinya. Sehingga lebih banyak orang yang akan menikmati hasil/dampak kepemimpinan seorang pemimpin (Mat 20:28; Mrk 10:45; Yoh 21:15-19; Ibr 13:17-21; 1 Ptr 3:13-23; Luk 17:10). Kepekaan Yesus ada pada kebutuhan manusia dan bukan pada apa yang diinginkan manusia.

Pelayan sebagai manusia memiliki konsep diri yang positif dan nilai diri yang mendasar agar pelayanan menjadi sehat dan baik. Walter Wiest dan Elwyn Smith mengatakan bahwa "Orang yang dipanggil menjadi pelayan selalu hidup dalam ketegangan antara watak dan kekurangan mereka serta tuntutan panggilan mereka."33 Prinsip pelayanan yang berlaku adalah memperhatikan kesehatan untuk meraih hidup dengan sukacita. Unsur pelayanan yang paling penting juga adalah gaya hidup yang tidak menggoyahkan injil yang diberitakan.

Pelayan adalah orang yang melayani dan peziarah iman. Kunci pelayanan yang efektif adalah pertumbuhan yang berkelanjutan pada diri pelayan. Menurut Maggay, Yesus mengirim para murid untuk melayani, instruksi-Nya mengandung dua komponen yaitu; pertama, proporsional, "Bertobatlah, karena Kerajaan Allah sudah tiba." Dan eksperiensial, sembuhkan orang sakit, bangkitkan yang mati, tahirkan yang kusta, dan mengusir setan. Proposisinya tidak berdiri sendiri, ia didukung dengan realitas. ${ }^{34}$ Pelayanan yang dimaksud menggunakan waktu untuk memenuhi kebutuhan baik jasmani maupun rohani.

\footnotetext{
${ }^{32}$ Yakob Tomatala, Kepemimpinan Kristen: Mencari Format Kepemimpinan Gereja yang Kontekstual di Indonesia, (Jakarta: YT Leadership Foundation, 2003), 42-46

${ }^{33}$ Joe E. Trull dan James E Carter, Etika Pelayanan Gereja (Jakarta: BPK Gunung Mulia, 2012), 85

${ }^{34}$ Melda Padilla Maggay, Transformasi Masyarakat (Jakarta: Cultivate Publishing, 2004), 16.
} 


\section{Perintah Allah}

Amanat Agung menurut Herlianto, bersifat dua demensional yaitu yang vertikal (pemberitaan verbal dan sakramen), dan horisontal (melakukan kehendak). ${ }^{35}$ Jemaat mula-mula dikenal dengan Kristen kerena hidup sebagai pengikut Kristus dalam diri mereka (Kis 11:26). Gereja harus melayani secara utuh dan seimbang. Gereja harus mengutamakan pelayanan rohani, tetapi gereja tidak boleh mengabaikan pelayanan jasmani. Bila gereja mengabaikan pelayanan rohani dan jasmani, berarti melalaikan fungsi utama di tengah dunia ini. Percuma kita membicarakan tentang ajaran utama dalam kekristenan, yaitu kasih, bila mengabaikan tanggung jawab sosial untuk membantu sesama yang mengalami kekurangan atau kelaparan (Yak 2:1418).Karena itulah gereja harus melayanikeseluruhan pribadi di masa kini, begitu juga mempersiapkan pribadi tersebut untuk keabadian, melayanitanpa mencari keuntungan, yang bersikap lemah lembut dan rendah hati, yang siap mengampuni dan lain-lain. ${ }^{36}$

\section{Pelayanan Yesus terhadap Rohani Pelayan}

Yesus melayani pada awalnya di Yudea, Ia menyucikan Bait Allah (Yoh 2:13-22). Makna penting yang Yesus lakukan adalah menjaga kesucian dan memperbaiki moral etika manusia. Pelayanan Yesus yang banyak dipakai adalah mengajar (Mat 4:23; Luk 6:17-19). Ia memakai tanya jawab, diskusi dan metode lain. Tugas yang Yesus emban selanjutnya adalah memberitakan injil. Percakapan dan bimbingan dalam Yohanes 3:1-21. Pelayanan mengadakan mujizat, yang sakit disembuhkan, yang lumpuh berjalan dan yang berduka dihiburkan. Yesus memberkati anak-anak untuk mengenal Juruselamatnya (Mat 19:13-15, Mrk 10:13-16, Luk 18:15-17).

Cara yang Yesus pakai dalam pengajaran adalah berkhotbah, dengan bercerita dengan perumpamaan, ia memakai tanya jawab, diskusi dan metode lainnya. Memberitakan injil, dalam pemberitaan-Nya, kadangkala penginjilan bersamaan dengan pengajaran dan kesembuhan bagi orang sakit karena kerajaan Allah dan kuasa-Nya harus dibuktikan. Percakapan dan bimbingan,

\footnotetext{
${ }^{35}$ Herlianto, Pelayanan Perkotaan (Bandung: Yabina, 1998), 132.

${ }^{36}$ Verne H. Fletcher, Lihatlah Sang Manusia! (Jakarta: BPK Gunung Mulia, 2007 ), 211.
} 
perlu perhatian. Yesus membimbing seorang perempuan Samaria, bahwa ia perlu air hidup (Yoh 4:4-26). Ia menyampaikan percakapan dan bimbingan kepada sekelompok orang melalui percakapan tentang kasus tertentu. Cara percakapan bimbingan digunakan kepada pelayanan secara khusus tanpa disaksikan orang banyak. Mengadakan mujizat, pelayanan ini adalah pertolongan yang ajaib kepada mereka yang disembuhkan. Yesus memberkati anak-anak agar mengenal dan menerima Kristus dalam hidupnya (Mat. 19:13-15, Mrk 10:13-16, Luk 18:15-17). Pelayanan Yesus terhadap kebutuhan jasmani. Pelayanan menyembuhkan, kepedulian Yesus. Perhatian Yesus pada penyembuhan orang yang sakit sebagai perwujudan Kerajaan Allah. Yesus mengusir setan serta menyembuhkannya (Mrk 1:21-28). Membangkitkan orang mati, terhadap lazarus yang dibangkitkan (Yoh 11:1-46).

\section{Pelayanan Politik}

Keutuhan pelayanan Yesus tidak lepas dari sikap politis untuk memperjuangkan hidup rohani akan keselamatan dan hidup jasmani manusia dari penderitaan, pembebasan dari kuasa setan dan keadilan. Perjuangan Yesus sampai kepada menderita dan mati di kayu salib adalah bagian dari sikap politis dari du kaca mata Kerajaan Romawi. Jika melihat keseluruhan konteks pelayanan Yesus terhadap orang sakit, pada dasarnya pelayanan penyembuhan Yesus ingin menekankan dua tujuan penting. Pertama ingin membawa manusia yang Ia sembuhkan kepada persekutuan dengan Allah dan mengalami kelimpahan berkat Allah yang seutuhnya (bd. Yoh 10:10). Konsep ini menjadi integral dalam seluruh prinsip dan metode pelayanan penyembuhan Yesus. Kedua, untuk memberi tanda kehadiran Kerajaan-Nya (Mat 12:27-28). Cara pengusiran roh jahat itu hanya sebagai alat untuk mencapai tujuan pelayanan itu sendiri.

Keseluruhan cara Yesus menyembuhkan tampak sangat kreatif dan variatif, tidak terbatas pada satu cara saja. Hal menarik dari pendekatan Yesus dalam pelayanan kesembuhan adalah, pendekatannya sangat personal oriented, bukan problem oriented. Anda tidak dapat memperlihatkan apapun yang lebih besar bagi dunia yang jahat ini selain dari pada kesan dan 
gambaran tentang kasih Allah pada karakter anda sendiri. ${ }^{37}$ Pribadi-Nya yang hangat dan penuh belas kasihan menjadi daya tarik dan menjadi sarana yang membawa kesembuhan. Pendekatan Yesus ini pada dasarnya pendekatan holistik.

\section{Kesimpulan}

Bagian akhir ini adalah merupakan pembahasan tentang penerapaan pola pelayanan Yesus bagi pelayan Sekolah Minggu Jemaat Tamalanrea, mencakup kesimpulan dan saran sebagai berikut:

Pelayan Sekolah Minggu Gereja Toraja Jemaat Tamalanrea melakukan pola pelayanan berdasarkan pekerjaan Kristus namun belum maksimal. Pelayanan dilakukan masih dalam rutinitas yang diprogramkan yakni menjenguk yang sakit dan memberikan hadiah bagi yang berulang tahun. Kemampuan untuk memotivasi anak, berempati dan membina hubungan baik dengan orang lain. Pelayan memiliki jiwa pendidikan dan memiliki sifat penuh kasih.

Pembinaan dan pengkaderan pelayan sekolah minggu, program lomba bercerita bagi orang tua yang memiliki anak umur di bawah sembilan tahun. Mengadakan evaluasi pembelajaran. Mengupayakan alat kreativitas anak, menyediakan perpustakaan. Menyediakan permainan untuk anak.

Pengaruh pola pelayanan Yesus bagi Pelayan Sekolah Minggu Gereja Toraja Jemaat Tamalanrea belum maksimal dalam tindakan yang berpengaruh terhadap hubungan pelayan dengan orang tua. Pelayan membutuhkan pembinaan agar memahami pelayanan anak dan menghargai orang yang lebih tua.

\section{KEPUSTAKAAN}

Abineno, J.L Ch. Pedoman Praktis Untuk Pelayanan Pastoral. Jakarta: BPK Gunung Mulia, 2006.

Anderson, Mavis L. Pola Mengajar Sekolah Minggu. Bandung: Kalam Hidup, 1993.

\footnotetext{
${ }^{37}$ Mavis L Anderson, Pola Mengajar Sekolah Minggu (Bandung: Kalam Hidup, 1993), 90.
} 
Bavinck, J.H. Sejarah Kerajaan Allah 2 Perjanjian Baru. Jakarta: BPK Gunung Mulia, 2007.

Capehart, Jody. Becoming a Treasured Teacher: Practical Strategies for Making a Lasting Difference in Young Lives. Victor Books, 1992.

Chandra, Robby I. Pendidikan Manusia Mandiri. Bandung: Generasi Indonesia, 2006.

David J. Bosch, Transformasi Misi Kristen. Jakarta: BPK Gunung Mulia, 2006.

E. P. Gintings, Konseling Pastoral. Jakarta: Jurnal Info Media, 2009.

Eckardt, Roy.Menggali Ulang Yesus Sejarah.Jakarta: BPK Gunung Mulia, 2006.

Fletcher, Verne H. Lihatlah Sang Manusia!. Jakarta: BPK Gunung Mulia, 2007.

Gibbs, Eddy. Kepemimpinan Gereja Masa Mendatang. Jakarta: BPK Gunung Mulia, 2010.

Gula, Richard M. Etika Pastoral Dilengkapi dengan Kode Etik. Yogyakarta: Kanisius, 2009.

Herlianto. Pelayanan Perkotaan (Bandung: Yabina, 1998.

Ismail, Andar (peny.), Ajarlah Mereka Melakukan. Jakarta: BPK Gunung Mulia, 2009.

Kadarmanto, Ruth S. Tuntunlah ke Jalan Yang Benar. Jakarta: BPK Gunung. 2005.

Ladd, George Eldon. Teologi Perjanjian Baru. Bandung: Kalam Hidup. 2002.

Leigh, Ronald W. Melayani dengan Efektif. Jakarta: BPK Gunung Mulia, 2007.

Leks,Stefan.Tafsir injil Markus.Yogyakarta: Kanisisus, 2007.

Lugo,Gunche.Manifesto Politik Yesus. Yogyakarta: Penerbit ANDI, 2009.

Maggay, Melda Padilla. Transformasi Masyarakat. Jakarta: Cultivate Publishing, 2004.

Napel, Henk Ten. Jalan Yang Lebih Utama Lagi. Jakarta: BPK Gunung Mulia, 1990.

Ngelow,Zakaria J. Gereja dan Masyarakat Madani di Indonesia.Jurnal Teologi Persetia, 1999.

Nggebu,Sostenis.Napak Tilas Jejak-Jejak Yesus. Bandung: Yayasan Kalam Hidup, 2004.

Olla, Paulinus Yan.Dipanggil Menjadi Saksi Kasih. Yogyakarta: Kanisius, 2011.

Petrus F. Setiadarma, “Motivasi Pelayanan”, diakses tanggal 16 Oktober 2012, tersedia di http://motivasi-pelayanan.html,

Ronda, Daniel Leadership Wisdom. Bandung: Kalam Hidup, 2011.

Rupp, Anne Neufeld. Tumbuh Kembang Bersama Anak. Jakarta: BPK Gunung Mulia, 2009.

Singgih, Emanuel Gerrit. Reformasi dan Transformasi Pelayanan Gereja Menyongsong Abad 21 Yogyakarta: Kanisius, 1997.

Subakti,E.B. Benarkah Injil Kabar Baik. Jakarta: BPK Gunung Mulia, 2008.

Tomatala, Yakob. Kepemimpinan Kristen: Mencari Format Kepemimpinan Gereja yang Kontekstual di Indonesia. Jakarta: YT Leadership Foundation, 2003. 
Tomatala, Yakob. Pemimpin Yang Handal. Jakarta: YT Leadership, 2003.

Trull, Joe E. dan James E Carter. Etika Pelayanan Gereja. Jakarta: BPK Gunung Mulia, 2012.

Wagner, C. Peter.Strategi Perkembangan Gereja. USA: Gospel Literature International, 1998.

Wilkes,G. Gene.Jesus on Leadership: Temukan Rahasia Pelayanan dari Kehidupan Kristus.

Jakarta: Bhuana Ilmu Populer, 2005.

\section{Lampiran}

Ezra Tari, Menyelesaikan studi S1 di STT Intim Makassar (S.Th/2010) dan program pascasarjana di STT Jaffray Makassar (M.Th/2013) konsentrasi Perjanjian Baru. Sekarang Dosen Perjanjian Baru di STAKN Kupang, Nusa Tenggara Timur. email: tariezra@gmail.com. Hp: 085299711068 